\title{
STRENGTHENING LAND REGISTRATION SYSTEM THROUGH IMPLEMENTATION OF DOMAIN APPROACH IN MANIFESTING LEGAL CERTAINTY AND COMMUNITY JUSTICE
}

\section{Nia Kurniati and Jordan Mordekhai}

Faculty of Law, University of Padjajaran, Jl. Raya Bandung-Sumedang KM. 21 Jatinangor, 456363

E-mail: nia.kurniati@unpad.ac.id; jordanmordekhai0@gmail.com

\begin{abstract}
As an implementation of welfare society, the government issued Law Number 5 of 1960 Article 19 paragraph (2) c, which provide the legal certainty of land rights for all Indonesians carried out through land registration. The land registration system adopted by Indonesia is negative land cadastre with positive tendency. The implementation of land registration provide the basis of state duty to produce land registration evidence, namely certificate, which is valid as a strong proof of rights. This certificate guarantees the correctness of physical data besides juridical data as long as it is not proven otherwise. Method: This legal research used Normative juridical method, with qualitative juridical data analysis. Results of the study: Negative land cadastre with positive tendency adopted by Indonesia currently does not guarantee legal certainty of land ownership and the community justice itself. This is indicated by the fact that there is still a phenomenon of land disputes, among the result of the issuance of overlapping. By using a legal cadastre-based domain approach, through an approach of extracting historical values of land and integrating the process of dialogue within the issuing of certificate; obtaining legal certainty and the community justice can be achieved. Conclusion: Negative land cadastre with positive tendency is still unable to manifest legal certainty of land ownership and community justice so it is appropriate that an adage states "the highest legal certainty, is the highest injustice". Strengthening land registration system through the domain approach is an alternative option to manifest legal certainty and community justice.
\end{abstract}

Key words: Land Registration; Legal Certainty; Justice; Land Cadastre-Based Domain Modelling

\section{PENGUATAN SISTEM PENDAFTARAN TANAH MELALUI PENERAPAN DOMAIN APPROACH DALAM MEWUJUDKAN KEPASTIAN HUKUM DAN KEADILAN MASYARAKAT}

\begin{abstract}
ABSTRAK. Sebagai perwujudan dari konsep kesejahteraan umum, pemerintah menerbitkan Undang-Undang Nomor 5 Tahun 1960 Pasal 19 ayat (2) c, yang berupaya memberikan jaminan kepastian hukum kepemilikan hak atas tanah bagi seluruh rakyat Indonesia melalui sistem pendaftaran tanah. Sistem pendaftaran tanah yang dianut Negara Indonesia, yakni sistem pendaftaran tanah negatif bertendensi positif memberikan dasar bagi tanggung jawab negara untuk menerbitkan bukti pendaftaran tanah berupa Sertifikat sebagai alat bukti hak yang kuat. Kekuatan hukum sertifikat menjamin kebenaran data fisik dan data yuridis sepanjang tidak dibuktikan sebaliknya. Metode Metode penelitian hukum yang digunakan adalah yuridis normatif, dengan analisis data secara yuridis kualitatif. Hasil penelitian: sistem pendaftaran tanah negatif bertendensi positif yang dianut Negara Indonesia belum menjamin kepastian hukum kepemilikan hak atas tanah dan rasa keadilan masyarakat secara sempurna. Hal ini ditunjukkan dari kenyataan yang ada, masih dijumpai fenomena sengketa tanah, antara lain akibat terbitnya sertifikat ganda. Dengan menggunakan sistem legal cadastre-based domain approach, melalui pendekatan penggalian nilai-nilai historis pertanahan serta proses musyawarah mufakat dalam proses penerbitan sertifikat; perolehan kepastian hukum dan rasa keadilan dapat dicapai, Kesimpulan: Sistem pendaftaran tanah negatif bertendensi positif masih belum dapat mewujudkan kepastian hukum kepemilikan hak atas tanah dan rasa keadilan masyarakat sehingga tepatlah suatu adagium yang menyatakan "kepastian hukum yang tertinggi, adalah ketidakadilan yang tertinggi". Penguatan sistem pendaftaran tanah melalui model pendekatan domain kiranya dapat menjadi alternatif pilihan untuk mewujudkan jaminan kepastian hukum dan keadilan masyarakat.
\end{abstract}

Kata Kunci : Pendaftaran Tanah; Kepastian hukum; Keadilan; Land Cadastre-Based Domain Modelling.

\section{INTRODUCTION}

Land registration problems are an integral part of agrarian problems specifically provided in Law No. 5 Year 1960 on Basic Regulations of Agrarian Principles Article 19 paragraph (2) c (hereinafter referred to as UUPA). Land registration problems are closely related to ownership of land rights by an individual or a legal entity as the legal subject holding the land rights. Therefore, land rights held by an individual or a legal entity on a certain plot of land will be protected by the law if it is registered at Land Registration Office of Regency/City, National Land Authority (BPN). BPN as the administrator of national land registration is authorized to issue a certificate as a proof of rights. Certificate is a strong legal proof (Harsono, 2019: 478) to guarantee legal certainty for the holder of rights.

General description Number I of UUPA states that the Law on Agrarian Principles (UUPA) has laid new valuable rationales in managing the legal relation between Indonesian people and earth/land, water, 
space, and wealth contained within, as contained in the main goals of UUPA, namely: (Harsono, 2019: 221)

a. Laying the foundation of National Agrarian Law drafting to be a tool to bring welfare, happiness, and justice for the state and the people, especially peasants, in order to manifest just and prosperous community;

b. Laying the foundation of unity and simplicity in laws on land registration;

c. Laying the foundation in providing legal certainty regarding land rights for all people.

In laying the foundation, the state requires land ownership to be registered in advance on behalf of the holder of rights in order for them to obtain legal certainty on his/her rights. It is also explicitly described in Article 19 of UUPA in which the Government instructs that, in all regions of Indonesia, rechtskadaster land registration has to be implemented that aims to guarantee legal certainty. It is expressly stated in the Fourth General Description of Law Number 5 Year 1960 on Basic Regulations of Agrarian Principles.

Furthermore, in Government Regulation Number 24 Year 1997 on Land Registration (hereinafter referred to as PP on Land Registration), Article 32 paragraph (1), it is stated that:

"Certificate is a valid proof of rights that serves as a strong evidence of physical data and juridical data contained therein, as long as the physical data and juridical data conform to the data contained in the corresponding land measurement certificate and land book of the rights. Description of Article 32 paragraph (1): Certificate is a strong proof of rights means that unless it is proven otherwise the physical data and juridical data contained therein have to be accepted as correct data. Certainly, the physical data and juridical data contained in the certificate have to conform to the data contained in the corresponding land book and land measurement certificate because the data are taken from the land book and land measurement certificate, so it is firm that certificate is a strong proof provided by the state to guarantee the rights and legal certainty as long as no one else proves otherwise regarding the ownership status. In case there no one else can reverse the burden of proof otherwise, a plot of land with a certificate issued is validly and really his/hers, and it can be settled through trial at court that furthermore the Panel of Judges decides that the holder of Certificate is not entitled to the plot of land, so the plot of land has to be surrendered to the entitled party and the Land Certificate has to be cancelled.
Legal force of Certificate as a strong proof causes a legal consequence that potential legal disputes on land are unavoidable every time. The occurrence of legal dispute on land comes from a person's complaint (individual/entity) containing objections and claims on land rights (Murad, 1991: 257).

To support the principle of legal certainty on land rights, at the end of 2019 has been implemented a program of legal certainty grant acceleration and legal protection on community land rights through Complete Systematic Land Registration (PTSL) based on Regulation of Minister of Agrarian and Spatial Planning / Head of National Land Authority of the Republic of Indonesia Number 6 Year 2018 on Complete Systematic Land Registration. According to information from BPN, in the implementation of PTSL, were found some cases of land disputes classified based on typology, namely:

a. Overlapping rights $33 \%$;

b. Procedure of determination and grant of rights $39 \%$;

c. Customary land 27\%;

d. Court decision $1 \%$.

Confirmation of land rights as an output of land registration process a person takes aims to manifest legal certainty and order for Indonesian people. Negative land registration system with positive tendency made as the basis of national land registration system is unable to guarantee the fulfilment of land rights for community welfare. Reviewed from the aspect of rights legality, the implementation of the system has triggered the occurrence of integral land conflicts and disputes due to sectoral conflict of interests (Kurniati, 2017:97). On the other hand, inefficient bureaucracy and inadequate extraction of historical values in data of land ownership have caused legal uncertainty because of inadequate accuracy of physical data and juridical data (Cardova, et.all., 2020:261). Therefore, the main problem needs to be detected as early as possible to minimize the occurrence of land disputes that lead to legal uncertainty of land rights and sense of community injustice.

Legal drafting needs to be guided by justice. It is the conception that needs to be built in national land registration system where the mainstreaming of principle of legal certainty has to be always accompanied by principle of justice. Therefore, it is not surprising that there is an adage that states summon ius, summa injuria, summa lex, summa crux, which means a law that sticks to a rigid system tends to hurt someone unless justice helps him/her 
(Rato, 2010: 59). In connection with that matter, it needs a strengthening of national land registration system so it can harmonize the two principles therein (legal certainty and justice) harmoniously and proportionally. Starting from the description, the writer offers a system adopted by other countries as a comparative study, namely Land CadastreBased Domain Approach as an effort to manifest legal certainty of land rights and community justice. The mechanism in the system is participatory by putting forward historical value approach in the process of land certificate issuance so potential occurrence of legal disputes in the future can be reduced as minimum as possible. On the other hand, manifestation of sense of justice can be fulfilled for all parties involved therein.

Following the problems above, the writer reviewed the two main problems in the study, namely:

1. Why is negative land registration system with positive tendency unable to guarantee legal certainty of land rights and conform to sense of community justice?

2. Is Land Cadastre-based Domain Approach able to guarantee legal protection on land rights and conform to community justice?

\section{METHOD}

In this study, the writer reviewed the problems using normative juridical research method, namely a study providing systematic exposure to regulations governing certain legal categories, analyzing correlation between regulations, describing areas experiencing obstacles, and even predicting future developments (Muhammad, 2004:52). Qualitative is a method of analysis of research results resulting in descriptive analytical data, namely data stated by respondents in writing or verbally and real behaviors studied and learned as something intact (Fajar \& Achmad, 2010:192-193). To obtain accurate and accountable information, the study implemented 3 (three) main approaches, namely (i) Legislation Approach, (ii) Case Approach, and (iii) Comparative Approach.

In legislation approach, the writer reviewed the conformity of legislation substance to the legal issues handled. In this case, the most recent issue to be discussed was closely related to problems of certificate issuance mechanism and inventory of problems contained therein connected to applicable statutory regulations. In addition, the writer also implemented case approach used as the analysis tool to analyze recent cases related to legal issues and made as discussion topic in a writing, especially legal issues that have obtained court decision with permanent legal force, related to land registration system and problems therein. The use of comparative approach to explore the essence of land registration legal system adopted by other countries, and the possibility of its implementation in land registration system implemented in Indonesia. In the study, the writer used legal materials to be analytical reviews, in form of:

1. Primary legal materials, namely authoritative legal materials, consisting of:

a. Law Number 5 Year 1960 on Basic Regulations of Agrarian Principles (State Gazette of the Republic of Indonesia Year 1960 Number 104, Supplement to State Gazette of the Republic of Indonesia Number 2043);

b. Government Regulation Number 24 Year 1997 on Land Registration (State Gazette of the Republic of Indonesia Year 1997 Number 59, Supplement to State Gazette of the Republic of Indonesia Number 3696);

c. Presidential Regulation Number 17 Year 2015 on Ministry of Agrarian and Spatial Planning (State Gazette of the Republic of Indonesia Year 2015 Number 18);

d. Presidential Regulation Number 20 Year 2015 on National Land Authority (State Gazette of the Republic of Indonesia Year 2015 Number 21);

e. Regulation of State Minister of Agrarian / Head of National Land Authority Number 3 Year 1997 on Provisions of Implementation of Government Regulation Number 24 Year 1997 on Land Registration as amended with Regulation of Head of National Land Authority Number 8 Year 2012 on Amendment of Regulation of State Minister of Agrarian / Head of National Land Authority Number 3 Year 1997 on Provisions of Implementation of Government Regulation Number 24 Year 1997 on Land Registration.

2. Secondary legal materials are in the form of literature that provides an explanation of secondary legal material consisting of books on defense, research results, papers, legal journals, articles, law magazines and various writings that have relevance to the object of research.

3. Tertiary legal materials are materials that provide explanations and instructions for primary and secondary legal materials, in this case a legal dictionary and encyclopedia or clippings from relevant printed or electronic media. 


\section{RESULTS AND DISCUSSION}

\section{The existence of a negative land registration system with a positive tendency as the basis for land registration in the Republic of Indonesia}

It is undeniable that humans in fulfilling their life and livelihoods cannot be separated from the existence of land. Land is the source of life and community survival. Realizing the importance of land for the survival of human society, the government in distributing land tries to establish a system to create order and guarantee prosperity to the widest possible community. One of the policy products legitimized by the authorities is the land registration system.

Theoretically, the birth of a land registration system or legal cadastre aims to guarantee legal certainty for ownership of land rights. The guarantee of legal certainty that will be realized from the existence of this system is the certainty of the status of rights that are registered, certainty of subjects and certainty of objects of rights. The output of the policy product produces a certificate as proof of ownership of rights. Through this certificate, the public obtains the correctness of information regarding physical data and juridical data on a plot of land that belongs to them so that if a dispute is encountered in the future, as long as the right holder can show the certificate as proof of legal ownership. (Santoso, 2015: 278) At the normative level, this idea has been accommodated accurately in each substance listed in Article 19 of the UUPA, which basically confirms that; the end of the registration activity land held by the Government is the granting of proof of rights, which acts as a strong means of proof. Then, in Article 32, the Government Regulation on Land Registration also affirms the same thing that; "The certificate is a strong proof of physical data and juridical data contained therein, as long as the physical data and juridical data are in accordance with the data contained in the relevant measuring letter and land title book". This has a kind of logical consequence that in the national land registration system, the Indonesian government tends to prioritize a negative registration system with a positive tendency where the presentation of data and information on the legal status of land rights must be presented correctly in its implementation (Harsono, 1999:88-90).

In the negative publication system, the Indonesian government adopts a system that if someone whose rights have been registered in a land book, in their rights there is still a possibility that there will be objections as long as the rebuttal can be proven by stronger evidence. In this case, this system still contains a number of weaknesses, namely that the government cannot guarantee the correctness of registered material information. (Budhayati et al., 2018: 130-131) This means that physical or juridical data contained in the certificate provides legal protection and must be accepted by the judge. as a true statement as long as other strong evidence does not prove otherwise. Therefore, the court has the authority to decide the validity of the evidence and if the certificate is not proven properly, all amendments and corrections will be made through a court decision, by the court accordingly. In other words, the adoption of this system provides the widest opportunity for all parties to prove correct ownership of rights (Sumanto, 2020: 1400-1401)

On the basis of these weaknesses, the Indonesian government was doing its best to transform the national land registration system into a positive publication system. As a result, in the 2015-2019 National Mid-Term Development Plan, the government has launched a positive publicity land registration system, where this policy is closely related to the strategic issue of Legal Certainty of Community Rights to Land. The policy is based on the reality that the negative publication system has had many implications, such as; disruption of national security stability, including threatening the integrity of the Unitary State of the Republic of Indonesia due to the high potential for conflict between communities and society and the government, as well as a decline in national economic welfare.

As described above, the national land registration system does not actually adhere to a purely negative system, but still has positive nuances in it. The positive content contained in the national land registration system is basically based on several things, namely;

a. in the administration of land registration, a certificate of title is valid which is used as a strong, and not absolute, means of proof, the land registration system uses a registration of titles system, not a registration of deed system;

b. The state does not guarantee the accuracy of the physical data and juridical data stated in the certificate;

c. Land registration officers are active in examining the accuracy of physical and juridical data;

d. The purpose of land registration is to guarantee legal certainty;

e. In order to balance the weaknesses of the negative system, there is a positive content contained in the national land registration system, namely in Article 32 Paragraph (2) that if a certificate of a land parcel has been issued in the name of a person or legal entity acquiring the land in good 
faith, there is another party who feels that he owns the land but within 5 (five) years from the issuance of the certificate does not file a written objection to the Head of the Land Office, he / she can no longer contest his rights over the land. (Suharyono, 2019: 52)

Therefore, it must be admitted that there are a number of weaknesses in this system, namely it does not provide legal certainty, let alone legal protection for both certificate holders and third parties who obtain land rights. (Urip Santoso, 2015: 308) The root of the dispute that arises in this system is the recognition of disputed non-written evidence besides the certificate as strong legal evidence (Kurniati, 2016:209) In the process of proof it is necessary to know that there are several types of evidence such as regulated in Article 1866 of the Civil Code and Article 164 HIR, among others;

a. Written evidence or documentary evidence,

b. witness evidence,

c. presumption,

d. confession and oath. (Fakhriah, 2020: 93)

On the other hand, the variety of evidence, both written and non-written, is alleged to be the right step to provide maximum legal certainty for the real right holders, but the side effect that arises is when the aspect of justice is minimal because the implementation of this system also has negative implications for the rights. - rights over land that still have the status of customary ownership using Letter $\mathrm{C}$ or better known as girik (customary land certificate) are considered as proof of rights. The power of proof in the status of this land is still free and complementary, so it depends on the judge's judgment and the support of other evidence that supports it. Supreme Court Jurisprudence in the MA. Reg. No. 84K / Sip / 1973 dated 25 June 1973 stated that; "The records that come from the village / land book with the status of Letter $\mathrm{C}$ cannot be used as a sign of ownership rights in the trial if it is not included with other supporting evidence". Meanwhile, both UUPA and PP Land Registration are firm. states that the strongest legal evidence is land certificates.

Apart from the root of the problem, on several occasions a number of latent problems have been encountered when in the process of issuing land certificates, there have been attempts by third parties to legalize all efforts to support the issuance of double certificates. In several cases, the author's team encountered various problems with the rise of overlapping cases or better known as double certificates includes in the integral land conflicts that occurred in the field, however, several Supreme Court decisions have consistently provided full anticipation of the emergence of this dispute, including;

a. Supreme Court decision number 976 K/Pdt/2015 dated November 27, 2015: “.... Whereas in assessing the validity of one of the 2 (two) certified authentic evidences, it is applicable that the rights certificate issued earlier is valid and legally binding."

b. Supreme Court Decision Number 290 K / Pdt/2016 dated May 17, 2016 and decision Number 143 PK/Pdt/2016 of the Supreme Court stated: "Whereas if a dual rights certificate arises, the strongest proof of rights is the certificate that was issued earlier ..."

c. The Supreme Court Decision Number 734 PK/ Pdt/2017 states: "Whereas if there are 2 authentic deeds found, then the principle that the certificate issued earlier is valid and legally binding on Building Use Rights Certificate (SHGB) Number 1458 which is then extended with a Building Use Right Certificate. (SHGB) Number 46/ Babakan Ciamis Ward on behalf of Co-Defendant I (PT Propelat) which was later sold by PT Propelat to Respondent for Reconsideration on February 11, 1993, first getting a Certificate of Use Rights Number 18 issued on November 11, 1998.

It should be noted carefully that in the process of issuing certificates, there may still be gaps for the parties to support the proving process in court. Some of these problems are presented in the table list as follows;

Table 1. Inventory Data on Issues of Overlapping Rights and Certificate Issuance Procedures

\begin{tabular}{|c|c|c|}
\hline $\mathrm{NO}$ & JUDICIAL DECISION & LEGAL CASE \\
\hline 1. & $\begin{array}{l}\text { Supreme Court Decision } \\
\text { Number } 3615 \mathrm{~K} / \\
\text { PDT/2015, Kasmawati, } \\
\text { VS Marisa Tambengi, } \\
\text { et al }\end{array}$ & $\begin{array}{l}\text { Certificate Issuance } \\
\text { Procedure: BPN is deemed } \\
\text { not to act professionally } \\
\text { by measuring the land and } \\
\text { registering double certificates }\end{array}$ \\
\hline 2. & $\begin{array}{l}\text { Bengkulu District Court } \\
\text { Decision Number 659/ } \\
\text { Pid.B/2018/PN Bgl }\end{array}$ & $\begin{array}{l}\text { BPN is not careful in } \\
\text { measuring the land because } \\
\text { there is land that has not been } \\
\text { measured and the issuance of } \\
\text { multiple certificates }\end{array}$ \\
\hline 3. & $\begin{array}{l}\text { Supreme Court Decision } \\
\text { Number } 86 \text { K/TUN/2015, } \\
\text { M. Adam vs Ir. Mohd. } \\
\text { Sanusi, et al }\end{array}$ & $\begin{array}{l}\text { Accurate measurements were } \\
\text { not carried out in the field and } \\
\text { the inaccuracy and actions } \\
\text { of the Defendant in issuing } \\
\text { a certificate for the second } \\
\text { time (double certificate) of } \\
\text { disputed land were contrary } \\
\text { to the prevailing laws and } \\
\text { regulations, among others }\end{array}$ \\
\hline
\end{tabular}

Source : Secondary data, 2020 
Following up on these data, it shows that the inaccuracy and the existence of non-authentic evidence in the land registration process are the main problems in the emergence of disputes in the issuance of land certificates. In addition, procedurally, the absence of more in-depth extracting of information, especially relating to the exploration of the historical values of land was not carried out optimally so that it proved to have caused many legal disputes in the end. Based on the jurisprudence that has been stated above, it can be seen that the rampant cases of overlapping or double certificates are due to incomplete physical and juridical data presented. (Smith, 2015 : 1013) In this case, it is not surprising that the courts consecutively consider that the previous certificate is used as a reference for authority for ownership of land certificates.

\section{Land Cadastre System Based On Domain Approach In Providing Legal Certainty And A Sense Of Community Justice}

The author agrees that the negative land registration system with positive tendencies is basically aimed at creating the rule of law for all parties. This means that the existence of this system is expected to be able to create a conducive atmosphere of order so that all parties can obtain their rights fairly. But in fact, the legal symptoms that appear in the field are in fact inversely proportional to the land cadastral system which tends to be rigid which tends to have the potential to create loopholes of injustice which have major implications for society. Therefore, it is necessary to establish a strengthening and structuring of the national land publication system in order to achieve an efficient and equitable land registration system.

Starting from this explanation, the author tries to offer an innovative land cadastre system that aims to accommodate the objectives of legal protection for land rights and justice. In this case, the legal cadastre system based on the Domain Approach as a land registration system based on the principles of Social Tenure is believed to be able to guarantee legal certainty and a sense of justice for the community. This system was adopted by Scandinavian countries such as Sweden, which prioritized exploring historical aspects in their registration system. (C. Lemmen et al., 2015: 537) Simply put, in practice, the system adopted shows an intensification of real control over real mastery of the system. land so that the status of objects for ownership of land rights (object-based rights) becomes real and clear (Paasch, 2005: 5) This means that there are efforts from all parties to be actively involved in disclosing all complete information, including the management of historical data relating directly to land objects during the process. issuance of certificates. (Paasch, 2004: 3)

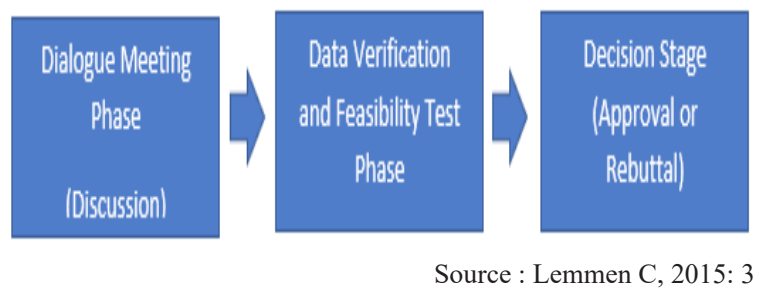

Figure 2. Stages Process of Land Cadastre Registration System based on Domain Approach

The presence of a cadastre-based domain legal procedure by prioritizing historical values actually provides maximum benefits for the rightholders to strengthen their proof of ownership during the issuance process of land certificate so that in the future, potential disputes can be reduced to a minimum. The realization of this domain system requires the involvement of all stakeholders in it. The stakeholders aforesaid among others: land surveyor agencies, land mediator institutions, parties who apply for certificates and third parties who are directly related to it (potential dispute parties). (C Lemmen, 2012: 78) In the process, the parties communicate with each other and exchange information about the accuracy of historical data on a land object, which cover;

a. Intensification of real tenure over land (historical temporal dimension/period of land tenure);

b. Work area (land area).

c. Suitability of land objects with the land designation system.

d. Spatial planning based on Geospatial Information Systems/ArcGIS mapping using the Spatial Reference System (Land \& Karlsson, 2005: 123)

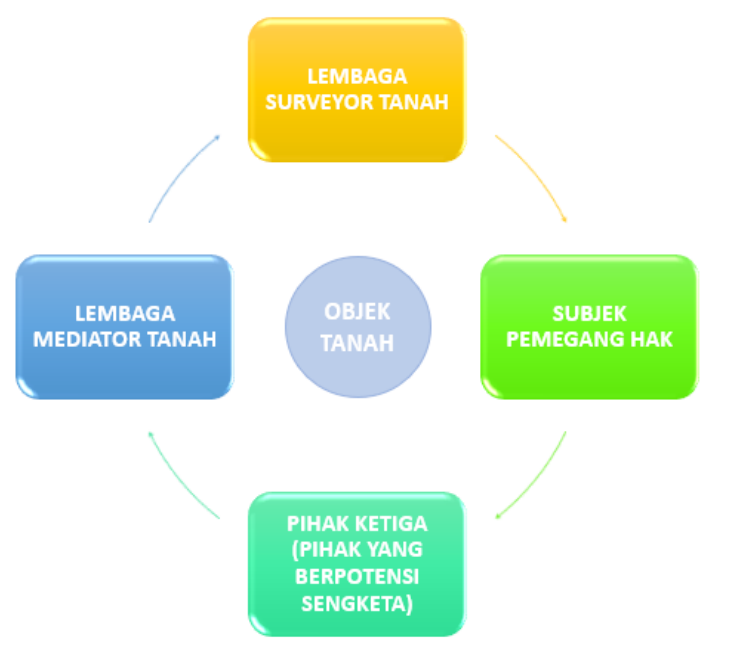

Source : Lemmen C, 2015: 3

Figure 3. Parties involved in the deliberative forum model in the Domain Approach model 
Accurate and correct data submission as described above can be delivered in a forum that brings together all parties involved as a forum for discussion facilitated directly by the government. In Indonesia, the institution that has the authority to bridge this meeting is the office of the National Land Agency. Through this forum, it is hoped that the certainty of juridical data and the accuracy of information can be guaranteed when this registration system is implemented. In addition, during the dialogue and consultation process, various conflicts and objections may arise during this deliberation process, but the presence of this system will actually result in resolutions that can be taken by the parties to resolve various existing problems, both in terms of land registration, and who holds the rights so that potential disputes in the future can be minimized as early as possible (Paasch, 2005: 5).

In the next stage of the scheme, namely data feasibility testing, all important information that has been previously obtained is accommodated and investigated legally and technically procedurally. This data testing stage plays an important role in ensuring that equal rights can be obtained for all parties so that justice can be achieved. Uniquely, the development of the Domain Approach model does not really involve the notary system to prove the correctness of the document. (Action, 2004) In this case, the term used in Indonesia is PPAT (Land Deed Making Officer held by a Notary). This means that the consequence that arises is the gradual simplification of the procedure for obtaining certificates. At another level, efforts to difunctional the role of notaries in issuing land certificates have actually opened up opportunities for the possibility of issuing an electronic-based certificate policy. That way, the notary in the future tends to carry out an audit function when there is a transfer of land rights so that it requires approval from a notary regarding the transfer deed.

In the last scheme, namely the decision stage, the government has the authority to decide whether to approve or reject the issuance of land certificates. At the approval stage, the National Land Agency as the official institution states that it agrees with the attached evidence because it is stated in accordance with the results of investigations conducted by the land surveyor agency. On the other hand, the National Land Agency also has the authority to refuse, when the results of the field survey conducted by the agency do not match and contradict the results of the deliberation forum and the legality of the evidence. In the future, central issues such as double certificates, fake or illegal attempts others can be resolved as early as possible because the accountability of the certificate issuance process is carried out openly and responsibly.

In practical terms, it must be admitted that this Domain-based cadastral model is quite suitable when applied to the Indonesian land registration system. On the one hand, the legal concepts accommodated in this model have a number of benefits contained in it, in terms of process the mechanism of land certificate issuance adopted by the Scandinavian country tends to be more efficient because it involves more active interaction processes in revealing historical evidence of land during the issuance process of land certificates. Therefore, in order to strengthen the process of issuing certificates in the national registration system, the Article 12 Paragraph (1) of the Government Regulation on Land Registration, confirms that; The land registration activities for the first time include: a. Physical data collection and management; $b$. Proof of rights and bookkjeeping; c. Issuance of certificates; d. Presentation of physical data and juridical data; e. Keeping public registers and documents. "Thus, to accommodate the renewal of the cadastral model adopted by Sweden, the Indonesian state could cut the process by including a dialogue meeting process by replacing the collection and management of physical data along with proof of rights and bookkeeping so as to simplify the existing mechanism because it includes these aspects in it. In fact, this evidence is supported by the verification and feasibility test stages of the data in rechecking the factual data so that the evidence presented will be more real and clear to the real owner.

From a legality perspective, it can be ascertained that the proof of land ownership submitted during the land certificate issuance process will ultimately guarantee more harmonious legal certainty and justice. This is confirmed in physical and juridical data that will be disclosed later, where information on the intensification of real control of land as historical evidence would become an important part of land document evidence presented in the certificate issuance process. The philosophical spirit that is tried to build in this concept actually bears little resemblance to the customary law system that tends to be more directed towards previous decisions. The essence contained in this cadastral model is important to be applied considering that in the coverage of Indonesia's land area, there are often cases that indicate the government's inaccuracy in presenting previous data so that it makes it easy for other parties to commit fraud in the legality of land ownership. Therefore, in an effort to prevent massive land disputes from arising in the future, it is necessary 
to reinforce Article 24, Government Regulation on Land Registration which reads;

"For the purposes of registration of rights, land rights originating from the conversion of old rights are proven by means of evidence regarding the existence of these rights in the form of written evidence, witness statements and/or statements of the concerned person whose levels are true by the Adjudication Committee in systematics land registration or by the Head of the Land Office in sporadic land registration, it is deemed sufficient to register the rights, rights holders and rights of other parties who impose them."

In this context, the aspect of strengthening the article can be in the form of a more participatory approach. In a sense, the involvement of all parties, including third parties who have the potential to become parties to the dispute, will be included in the land registration process, namely in the dialogue stage which is accommodated in a forum, so that in the future, the process of submitting evidence regarding the basis of land rights is more objective and fulfilling. elements of justice in it.

The system accommodated by Indonesia tends to prioritize the process of proving the legality of land ownership after the issuance of a land certificate so as to open the pathways for dispute resolution if there are parties who are dissatisfied with decisions that cause losses, whether through a mediation process, namely through the National Land Agency as the mediator who is authorized to resolve various land problems as stated in the Head of National Land Agency Regulation No.11 of 2016 concerning Settlement of Land Cases and the litigation process, until court decisions are issued with permanent legal force. (Kurniati \& Fakhriah, 2017: 96) This kind of approach is considered too obsolete so that there is a need for reform of a more comprehensive land registration system by accommodating the principles of legal certainty and justice in it. In this case, the Domain Approach in the land cadastre can be a pilot model adopted by the Indonesian state that is imbued with historical and participatory aspects in the process of land registration activities.

\section{CONCLUSION}

The negative registration system has a positive tendency, which was initially intended to guarantee legal protection for the parties, giving birth to legal uncertainty and injustice for the community. Although in it trying to integrate the various weaknesses and strengths of the system. The existence of double certificates and the government's inaccuracy in taking care of land registration indicates that the problem of overlapping rights and inefficient certificate issuance procedures is still a central problem that characterizes agrarian conflicts so that an adage is appropriate which states that; "The highest legal certainty is the highest injustice".

In effort to balancing these two aspects and strengthening the national registration system, it is possible to offer the Legal Cadastre Based Domain Approach system as an alternative solution to obtain a guarantee of legal certainty and proportional justice for the parties concerned. In addition, the application of this system is expected to minimize land conflicts/ disputes in the future.

\section{REFERENCES}

Budhayati, C.T. (2018). Jaminan Kepastian Kepemilikan Bagi Pemegang Hak Atas Tanah Dalam Pendaftaran Tanah Menurut UUPA. Jurnal REFLEKSI HUKUM. 2(2). 130-131.

Cardova, I. (2020). Kekuatan Hukum Sertipikat Tanah Yang Dikeluarkan Oleh Badan Pertanahan Nasional (Studi Kasus Putusan Mahkamah Syar'iah Banda Aceh Nomor 223/Pdt.G/2017/Ms.Bna). Jurnal IUS Kajian Hukum dan Keadilan. 8(2). 261

Fajar, M, Yulianto, A. (2010). Dualisme Penelitian Hukum Normatif dan Empiris. Yogyakarta: Pustaka Pelajar.

Fakhriah, E.L. (2020). Penemuan Hukum Oleh Hakim Melalui Pembuktian Dengan Menggunakan Bukti Elektronik Dalam Mengadili Dan Memutus Sengketa Perdata. Jurnal Bina Mulia Hukum, 5(1):89-102

Harsono, B. (1999). Hukum Agraria Indonesia. Edisi revisi. Jakarta: Djambatan. 88

Harsono, B. (2019). Hukum Agraria Indonesia: Sejarah Pembentukan Undang-Undang Pokok Agraria, Isi dan Pelaksanaannya. Jilid 1 Hukum Tanah Nasional. Jakarta: Penerbit Universitas Tri Sakti.

Kurniati, N. (2016). Mediasi-Arbitrase Untuk PenyelesaianSengketa Tanah,Sosiohumaniora, 18(3), 197-207

Kurniati, N. \& Fakhriah, E.L. (2017). BPN Sebagai Mediator Dalam Penyelesaian Sengketa Tanah Di Indonesia Pasca Perkaban No. 11 Tahun 2016, Sosiohumaniora, 19(2). 96-97

Land, K., \& Kristin Karlsson, F. N. (2005). A Future Legal Coordinated Cadastre for Sweden?. 
Paper presented at International Symposium \& Exhibition on Geoinformation 2005, Penang, Malaysia. 5

Lemmen, C. (2012). A Domain Model for Land Administration, Delft: Geodesy. 78 Nederlandse Commissie voor Geodesie, Netherlands Geodetic Commission. 60Rahmatia, \& Syahira. (2020). The Student Perspectives on the Effectiveness ofMedia Zoom Meeting in Increasing Knowledge of Thesis Writing at STKIP Muhammadiyah Manokwari. International Journal of Education Information, 3(2), 333-337. https:// doi.org/10.5281/zenodo.3987204

Lemmen, C., Oosterom, P. \& Bennett, R. (2015). The Land Administration Domain Model, Journal Land Use Policy. 49. 535-545.

Murad, R. (1991). Penyelesaian Sengketa Hukum Atas Tanah. Bandung : Alumni.

Paasch, J.M. (2005). A Legal Cadastral Domain Model. Forthcoming article in the Nordic Journal of Surveying and Real Estate Research. 5

Paasch, J.M. (2004). 'FIG Commission 7' and 'COST Action G9' Workshop on Standardization in the Cadastral Domain Bamberg, Paper Presented at Germany, 9 and 10 December 2004. 3

Paasch, J.M. (2005), Legal Cadastral Domain Model - An Object-oriented Approach, Nordic Journal of Surveying and Real Estate Research. 2, 123.

Rato, D. (2010). Filsafat Hukum Mencari: Memahami dan Memahami Hukum. Yogyakarta: Laksbang Pressindo.

Suharyono. (2019). Legal Assurance and Legal Protection. Sriwijaya Law Review, 3(1), 52

Santoso, U. (2015). Hukum Agraria: Kajian Komprehensif. Jakarta : Prenamedia Group.
Santoso, U. (2015). Pendaftaran dan Peralihan Hak Atas Tanah, Jakarta : Prenamedia Group.

Smith, R. (2015). Land Registration: Rectification And Purchasers. The Cambridge Law Journal. 74(1). 10-13

Sumanto, L. (2020). The Future On Publication System Of Land Registration In Indonesia, International Journal of Scientific \& Technology Research. 9(03).

Undang-Undang Nomor 5 Tahun 1960 tentang Peraturan Dasar Pokok-Pokok Agraria (Lembaran Negara Republik Indonesia Tahun 1960 Nomor 104, Tambahan Lembaran Negara Republik Indonesia Nomor 2043);

Peraturan Pemerintah Nomor 24 Tahun 1997 tentang Pendaftaran Tanah (Lembaran Negara Republik Indonesia Tahun 1997 Nomor 59, Tambahan Lembaran Negara Republik Indonesia Nomor 3696);

Peraturan Presiden Nomor 17 Tahun 2015 tentang Kementerian Agraria dan Tata Ruang (Lembaran Negara Republik Indonesia Tahun 2015 Nomor 18);

Peraturan Presiden Nomor 20 Tahun 2015 tentang Badan Pertanahan Nasional (Lembaran Negara Republik IndonesiaTahun 2015 Nomor 21);

Peraturan Presiden Republik Indonesia Nomor 2 Tahun 2015 Tentang Rencana Pembangunan Jangka Menengah Nasional 2015-2019 (Lembaran Negara Republik Indonesia Tahun 2015 Nomor 3)

Peraturan Kepala Badan Pertanahan Nasional Nomor 8 Tahun 2012 tentang Perubahan atas Peraturan Menteri Negara Agraria/ Kepala Badan Pertanahan Nasional Nomor 3 Tahun 1997 tentang Ketentuan Pelaksanaan Peraturan Pemerintah Nomor 24 Tahun 1997 tentang Pendaftaran Tanah 